\title{
00 高分子科学最近の進歩
}

\section{高分子／有機材料の電界発光}

\section{城戸 淳二}

Junji Kido, 山形大学工学部

\section{1.はじめに}

乾電池で蛍光灯以上の明るさの発光が得られ, しか も赤, 緑, 青の三原色济加兑, 白色光の面発光素子が できるとしたら，そのインパクトは計り知れない.こ の夢のような発光素子が今，高分子などの有機材料を 用いて実現しようとしている。

有機材料が高電界下において発光する現象は電界発 光（エレクトロルミネッセンス）、と呼ばれ, その研究 は 1960 年代にアントラセン単結晶において見い出さ れて以来，現在まで続いている。しかし，表示素子へ の利用が特に注目され始めたのは，80 年代後半にな って Tang ら ${ }^{1)}$ の薄膜積層型エレクトロルミネッセン 卜素子 (EL 素子). の発表からであり, それ以来, 多 くの大学, 企業の研究所等で実用化に向けて本格的な 研究が始まった。

ここでは, 最近の報告から有機 EL 材料の現状につ いて，発光体の観点から材料別に解説する.

\section{2. 有機材料の電界発光}

有機蛍光色素を発光させるには，まず色素を何らか の方法で励起する必要があるが，電界発光の場合はこ れを電気的に行う。正確には電気化学的にラジカルカ チオン (ホール) とラジカルアニオン（電子）を固体 膜中で生成させ，それらの反応から励起種をつくる. EL 素子は一般には図 1 に示すような $1000 \AA$ 程度の 有機色素薄膜を陽極のITO 透明電極と陰極の金属電 極で挾んだ単純な構造をしており，有機層が単一組成 の材料から成る単層型や，複数の異なる種類の材料を 積層した積層型がある.上記の化学反応は電極付近で

Electroluminescence in Polymer and Organic Materials

高分子 43 巻 4 月号 $\quad(1994$ 年)
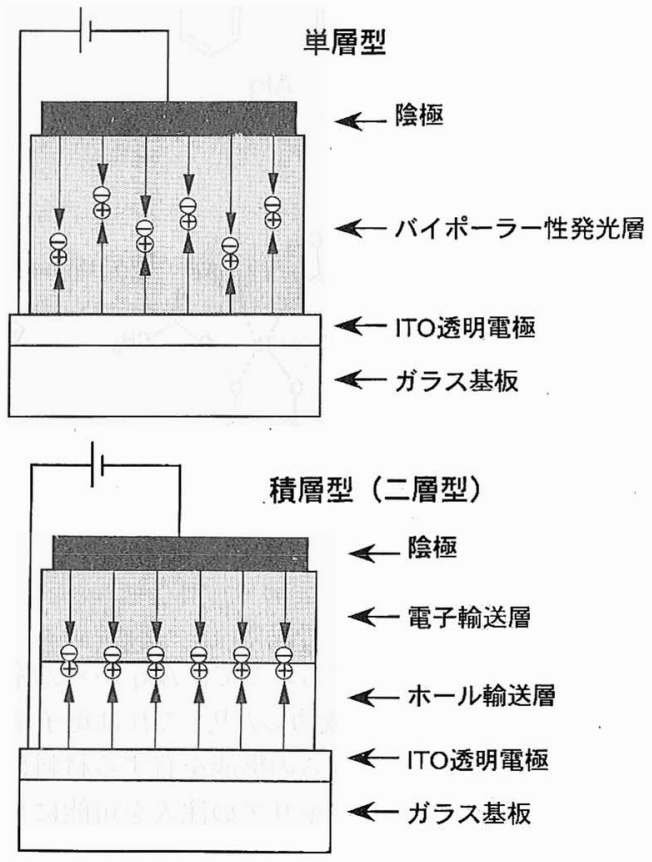

図 1 典型的な有機 EL 素子の構造

有機層に注入されたキャリア（ホールや電子）が高電 界下において対極にホッピング移動する途中で起こ り,ょく知られた溶液中での電気化学発光と原理的に は同じで, 有機 EL 素子の場合はこの反応が固体膜中 で起こるのである。

\section{3. 金属錯体系}

Tang らは電子輸送性（電子受容性）のトリス（8キノリノラト) アルミニウム錯体 (Alq) を発光層と して用い，この発光層と陽極間にホール輸送性（電子 供与性）のトリフェニルアミン誘導体 (TPAC) 層を

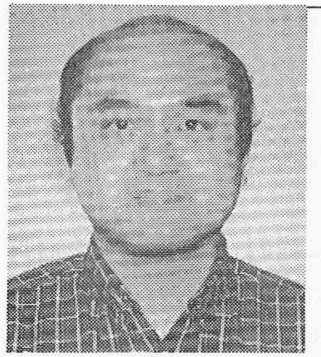

城戸淳二 山形大学工学部物質 工学科 (992 米沢市城南 4-316) 助手, Ph. D.

1984 年早大理工学部応用化学 科卒. 1989 年 Polytechnic Univ, 大学院博士課程修了。 1989 年より山形大. 1990 93 年 Brookhaven National Laboratory 客員研究員. 專門は有 機電子・光機能性材料.

<趣味〉暴飲暴食 
<smiles>c1cnc2c(O[PH]3(Oc4cccc5cccnc45)Oc4cccc5nccc(c45)O3)cccc2c1</smiles>

Alq

図 2 金属錯体系発光剤

$\mathrm{Tb}$ (acac)

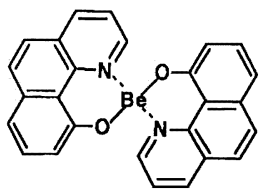

Bebq<smiles>C[C@](OC(=O)c1cccs1)(OC(=CC(=O)c1cccs1)C(F)(F)F)[Ge](OC(=CC(=O)c1cccs1)C(F)(F)F)(OC(F)(F)F)C(F)(F)F</smiles>

Eu(TTFA)

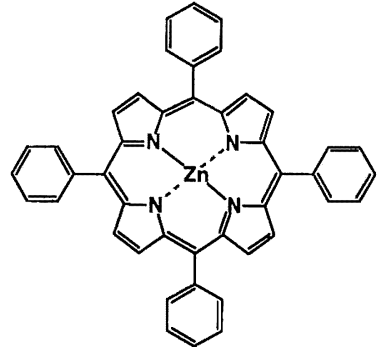

ZnPor

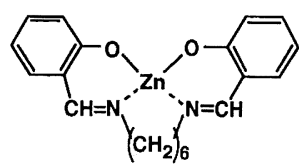

AZM-Hex
挿入した積層構造を採用することで, Alq から効率よ い発光を取り出すことに成功した ${ }^{1)}$. これは電子輸送 とホール輸送の役割をそれらの機能を有する材料に分 担させ，バランスよい両キャリアの注入を可能にした ことによる.この二層型素子からは $10 \mathrm{~V}$ 以下の低電 圧で $1,000 \mathrm{~cd} / \mathrm{m}^{2}$ 以上の高い輝度の緑色発光が得ら れ, 最高輝度も 1 万 $\mathrm{cd} / \mathrm{m}^{2}$ を越える. カラーテレビ やパソコンモニターの輝度が $100 \mathrm{~cd} / \mathrm{m}^{2}$ 程度であり, 蛍光灯が数千 $\mathrm{cd} / \mathrm{m}^{2}$ であることを考えると，この素 子がいかに明るいか想像がつく，現在，陰極材料にリ チウム合金を使用し，Alq 層に蛍光色素をドープする ことにより 10 万 $\mathrm{cd} / \mathrm{m}^{2}$ の高輝度が可能になってお り, 効率も約 4\% と実用化レベルにある2).

最近では Alq より優れた錯体も見い出されており, 構造の類似したベンゾキノリノラトを配位子に有する ベリリウム錯体 (Bebq) を発光層に用いた二層型素子 で $19,000 \mathrm{~cd} / \mathrm{m}^{2}$ の高輝度緑色発光が得られている3).

また，青色発光を示す金属錯体はアゾメチン系の配 位子が有効であり，亚鉛錯体（AZM-Hex）において $1500 \mathrm{~cd} / \mathrm{m}^{2}$ の高輝度発光が得られている4). また赤色 発光も亜鉛ポルフィリン錯体 (ZnPor) で $600 \mathrm{~cd} / \mathrm{m}^{2}$ に近い輝度が得られており5)，どの色に関しても，金 属錯体系だけで実用化に十分な高い輝度を得ることが できる。

テルビウムやユウロピウムに代表される希土類金属 錯体は $\mathrm{f}-\mathrm{f}$ 遷移に基づく非常に鋭い発光スペクトルを 有し，他の有機発光体に比べ色純度が格段に高い. 特
にユウロピウムはカラーテレビの赤色発光体としてす でに用いられているほどである，有機 EL 素子におい てもトリス（アセチルアセトナト）テルビウム錯体 $(\mathrm{Tb}(\mathrm{acac}))$ やトリス（テノイルフロロアセトナト） ユウロピウム錯体 (Eu (TTFA)) が発光中心として 用いられ, 色純度の高い発光色が得られている ${ }^{6) ~ 8)}$. ただ，輝度が他の錯体系より低く，今後実用化に向け ての高輝度化が望まれる。

\section{4. 低分子色素系}

低分子系の材料では, 種々のトリフェニルアミン誘 導体 (TPA) が合成され, これらの材料がホール輸送 性発光層として有効に機能することが見い出されてい る ${ }^{9)}$. た, 種々のオキサジアゾール誘導体 (OXD) についても, EL 特性が系統的に検討されており,こ の種の材料が電子輸送性発光層として機能するばかり でなく，置換基に電子供与性基を導入することによ り, ホール輸送性の発光層としても機能することが報 告されている10).

ジスチリル誘導体 (DSty) の電界発光特性も種々の 置換基を導入したものが合成され検討された ${ }^{11)}$. 青色 発光を示す電子輸送性色素には積層型素子においてホ 一ル輸送材料とエキシプレックスなどの錯体を形成す るものが多いが，置換基の導入により分子の平面性を なくし立体的に錯形成を不可能にする方法が提案され た.この系では最高 $6000 \mathrm{~cd} / \mathrm{m}^{2}$ もの高輝度青色発光 を示す材料があり注目に值する。 
<smiles>CCN(CC)c1ccc2cc(-c3nc4ccccc4s3)c(=O)oc2c1</smiles><smiles>O=c1c2ccccc2[nH]c2cc3c(=O)c4ccccc4[nH]c3cc12</smiles>

Qn

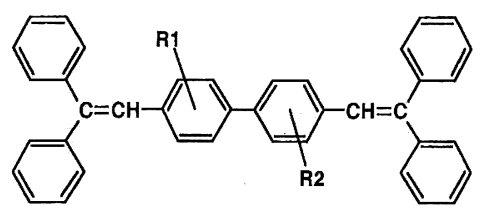

DSty
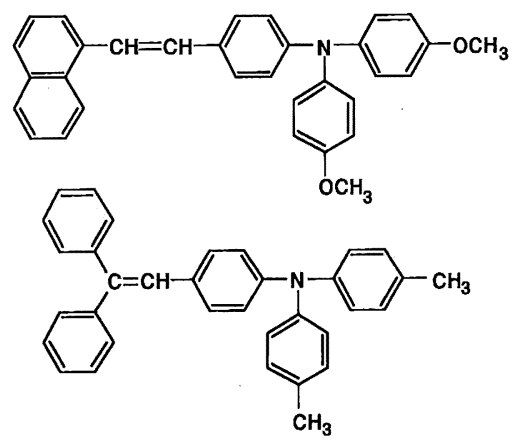

TPA
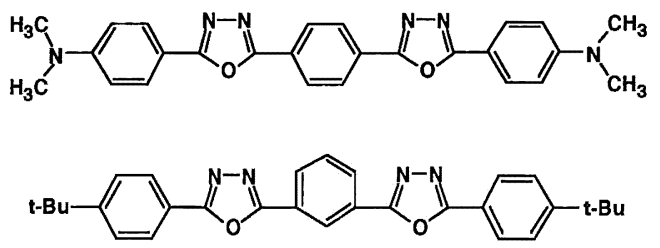

OXD

図 3 低分子色素系発光剤

5. 共役ポリマー系

一般に導電性ポリマーと呼ばれる共役系ポリマーの 中にはポリフェニレンビニレン (PPV) のように蛍光 性を有するものがあり, その電界発光挙動が調べられ ている ${ }^{12)}$.ポリマー系においても, 発光メカニズムは
先の低分子材料における電界発光と基本的には同じ で, ラジカルカチオンとラジカルアニオンの反応によ る励起子の生成が関与すると思われる。したがって, ホール輸送性である PPV を用いた単層型素子ではホ 一ルに対する電子の注入が十分ではなく, 高輝度の発 光は得られていない12).このことは後にキャリア輸送<smiles>CCOc1cc(/C=C(\C)c2cc(OC)c(OC)cc2/C(C#N)=C/C(C)(C)C)c(OC)cc1OCC</smiles>

CN-PPV

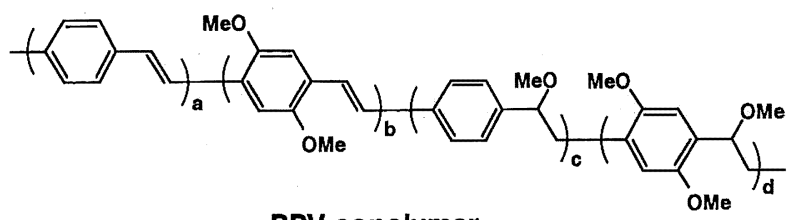

PPV copolymer

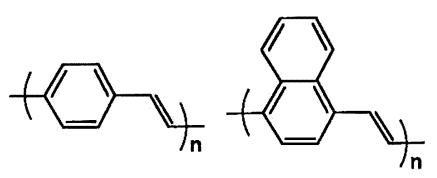

PPV

PA

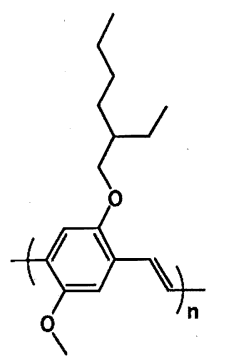

MEH-PPV

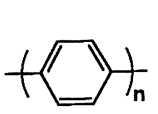<smiles>C=Cc1cc(C(C)(C)C)sc1C(C)(C)C</smiles>

PAT

PP<smiles>C=CC1Cc2ccccc2-c2ccc(C)cc21</smiles>

PAF

図 4 共役ポリマー系発光剤 


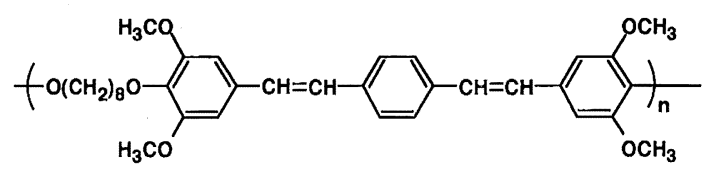

DS-PE

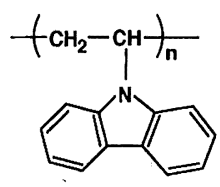

PVK

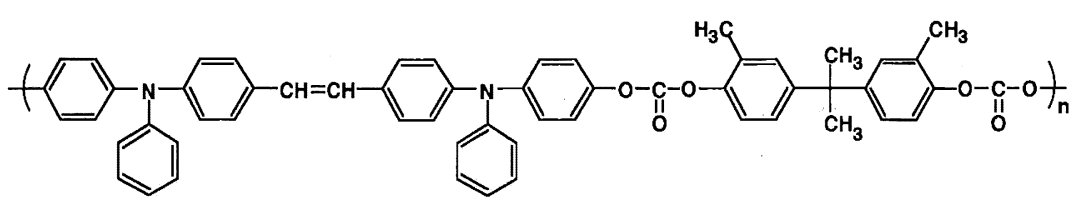

SA-PC

図 5 電荷輸送ポリマー系発光剤

性の異なる材料と積層型にすることにより改善されて いる ${ }^{13), 14)}$. 最近の報告では主鎖に電子吸引性のシア ノ基を導入し電子輸送性を付与したポリマー（CN$\mathrm{PPV})$ とホール輸送性の PPV との積層型で発光量子 収率が 4\%の高効率素子が作製されている ${ }^{15)}$.

PPV 系のユニークな点として素子のパターニング が可能なことがある ${ }^{16)}$.これは酸触媒でポリマー主鎖 から $\mathrm{MeOH}$ が脱離し, 共役が伸び, 発光色が異なる ことを利用している。

また，PVV 誘導体ポリマーを用いて，フレキシブ ルな素子も試作されている17).この素子では基板にポ リエチンンテレフタレート，陽極にポリアニリンを使 用し，陰極を除いたすべての材料がポリマーで構成さ れている。

他にもポリアルキルチオフェン $(\mathrm{PAT})^{18), 19)}$ やポリ アルキルフルオレン $(\mathrm{PAF})^{20)}$, ポリフェニレン $(\mathrm{PP})^{21)}$, ポリアリレン $(\mathrm{PA})^{22), 23)}$ 系の共役ポリマー が発光体として使用されているが，材料自体の蛍光量 子収率の低さ，あるいは不純物による消光作用のため か, 高い輝度の発光は得られていない.

\section{6. 電荷輸送ポリマー系}

上記の共役ポリマー系材料では共役系であるので, 発光波長が長波長側の緑色や赤色がほとんどであり， 高輝度青色発光が得られていない. そこで機能性基を 主鎖に組み込んだ非共役系ポリマーが合成され，その 特性が試されている。たとえばトリフェニルアミン誘 導体を主鎖に有するポリカーボネート (SA-PC) ${ }^{26)} や$ ジスチリル誘導体を主鎖中に導入したポリマー（DSPE) ${ }^{27)}$ において青色発光が観測されている.

また, 最近ホール輸送性かつ青色の蛍光を有するポ リビニルカルバゾール (PVK) を電子輸送層と組み合
わせた積層型素子において, PVK から $700 \mathrm{~cd} / \mathrm{m}^{2}$ を 越える高輝度青色発光が得られている ${ }^{37)}$.

\section{7. 分子分散ポリマー系}

単層型の素子で高効率発光を得るには, 発光層がホ ールと電子の両キャリアをバランスよく輸送し, 再結 合効率を高める必要がある。そこでポリマー中にキャ リア輸送剤を分子分散し, 望みのキャリア輸送性をポ リマー層に付与する試みがなされている.

ホール輸送性の PVK に電子輸送性のオキサジアゾ ール誘導体を分子分散させ, ポリマー層に電子輸送性 を持たせバイポーラー性を与えるのに成功した例があ る ${ }^{29)}$. 素子構成は先に述べた共役系ポリマーの場合と 同様, 単層型であるが, ポリマー層中に少量（約 1\%）のクマリンなどの発光剤を分子分散させること により，1,000 cd/ $/ \mathrm{m}^{2}$ を越える高輝度発光が得られて

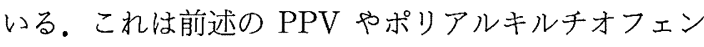
の単層型素子よりもはるかに輝度が高く, 単層型素子 に扔ける発光層のバイポーラー性の重要さを認識させ るものである.

また電気的, 光学的に不活性なポリメチルメタクリ レートにホール輸送剤と電子輸送剤をともに分子分散 することにより，ポリマー膜にバイポーラー性を付与 した単層型素子も作製されている30),31).ここではホ ール輸送性材料としてはトリフェニルアミン誘導体, 電子輸送性材料として Alq を適度に分散させ，キャ リアの再結合効率を高めている。この素子からは $1,000 \mathrm{~cd} / \mathrm{m}^{2}$ 程度の Alq からの緑色発光が得られ, 少 量の第三成分であるクマリンや DCM などの色素を加 えることにより, 発光効率が向上し，発光色も緑色よ りも長波長側へシフトさせることができる.

このような単層型素子では再結合効率を分散するキ 
ヤリア輸送剤の種類と濃度を変化させるだけで簡単に 最適化でき, 複雑な分子設計なしに膜にバイポーラー 性を与え，容易に素子を最適化することができるのが 特徴である。

積層型素子においても分子分散ポリマーは発光色の 多色化において非常に有効であり, 先の PVK を発光 層とする積層型素子において PVK 層中に少量の蛍光 色素を分子分散する事により発光色を変化させること ができる、特にこの系ではホストである PVK の発光 ピークが青色より短波長側にあるので基本的に可視領 域の光はすべてこの系で実現することができ, 実際, 青色, 緑色, 赤色発光が得られている ${ }^{32)}$. また, 青, 緑，赤の三種の色素を分散することにより，蛍光灯な みの高輝度白色発光を得るのに成功している ${ }^{33)}$. この ように分子分散ポリマー系は低分子材料の長所とポリ マー材料の長所を合わせて持ち，この系の優位性が認 識され始めた。今後ますます分子分散ポリマー系にお ける研究が増えるものと考えられる。

\section{8.おわりに}

有機材料の電界発光を利用した有機 EL 素子は現時 点でも LED や無機 EL 素子など既存の発光素子に匹 敵，あるいはそれらを越える特性を有するものであ る. 特に三原色の発光が直流低電圧で高輝度で得られ ることや，面状発光であることなどから，ディスプレ イとして理想的な特性を備えている。また，有機材料 は耐久性の点で問題があるとされてきたが, その問題 も分子設計により，ようやく解決しつつある。これも 有機材料の柔軟性によるところが大きく, 無機材料に はない有機材料の特幑が生かされている。あと数年で 21 世紀であるが，次世代のディスプレイとして有機 EL 素子は確実に進歩している.

\section{文献}

1) C.W. Tang, S.A. VanSlyke : Appl. Phys. Lett., 51, 913 (1987)

2) T. Wakimoto, R. Murayama, H. Nakada, K. Imai, G. Sato, M. Nomura: Polym. Preprints, 40, 3600 (1991)

3) Y. Hamada, T. Sano, M. Fujita, T. Fujii, Y. Nishio, K. Shibata: Chem. Lett., 905 (1993)

4) Y. Hamada, T. Sano, M. Fujita, T. Fujii, Y. Nishio, K. Shibata: Jpn. J. Appl. Phys., 32, L511 (1993)

5) Y. Hamada：応用物理学会, 有機分子・バイオエレク トロニクス分科会第 3 回講習会予稿集, p.83 (1993)

6) J. Kido, K. Nagai, Y. Ohashi : Chem. Lett., 657 (1990)

7) J. Kido, K. Nagai, Y. Okamoto, T. Skotheim: Chem. Lett., 1267 (1991)
8) J. Kido, K. Nagai, Y. Okamoto: J. Alloys and Compounds, 192, 30 (1993)

9) C. Adachi, T. Tsutsui, S. Saito : Appl. Phys. Lett., 56, 799 (1990)

10) Y. Hamada, C. Adachi, T. Tsutsui, S. Saito: Jpn. J. Appl., Phys., 31, 1812 (1992)

11) M. Matsuura, H. Higashi, H. Tokailin, C. Hosokawa, T. Kusumoto: 応用物理, 62, 1015 (1993)

12) J.H. Burroughes, D.D.C. Bradley, A.R. Brown, R.N. Marks, K. Mackay, R.H. Friend, P.L. Burns, A.B. Holmes: Nature, 347, 539 (1990)

13) A.R. Brown, D.D.C. Bradley, J.H. Burroughes, R.H. Friend, N.C. Greenham: Appl. Phys. Lett., 61, 2793 (1992)

14) A.R. Brown, N.C. Greenham, J.H. Burroughes, D.D. C. Bradley, R.H. Friend, P.L. Burn, A. Kraft, A.B. Holmes: Chem. Phys. Lett., 200, 46 (1992)

15) N.C. Greenham, S.C. Moratti, D.D.C. Bradley, R.H. Friend, A.B. Holmes: Nature, 365, 628 (1993)

16) P.L. Burn, A.B. Holmes, A. Kraft, D.D.C. Bradley, A.R. Brown, R.H. Friend, R.W. Gymer : Nature, 356, 47 (1992)

17) G. Gustafsson, Y. Gao, G.M. Treacy, F. Klavetter, N. Colaneri, A.J. Heeger: Nature, 357, 477 (1992)

18) Y. Ohmori, M. Uchida, K. Muro, K. Yoshino : Jpn. J. Appl. Phys., 30, L1938 (1991)

19) D. Braun, G. Gustafsson, D. McBranch, A.J, Heeger : J. Appl. Phys., 72, 564 (1992)

20) Y. Ohmori, M. Uchida, K. Muro, K. Yoshino:Jpn.J. Appl. Phys., 30, L1941 (1991)

21) G. Grem, G. Leditzky, B. Ullrich, G. Leising : $A d v$. Mater., 4, 36 (1992)

22) D. Braun, A.J. Heeger: Appl. Phys. Lett., 58, 1982 (1991)

23) M. Onoda, M. Uchida, Y. Ohmori, K. Yoshino : Jpn. J. Appl. Phys., 32, 3895 (1993)

24) C. Hosokawa, H. Higashi, T. Kusumoto: Appl. Phys. Lett., 62, 3238 (1993)

25) Z. Yang, I. Sokolik, F.E. Karasz: Macromolecules, 26, 1188 (1993)

26) J. Kido, K. Hongawa, K. Okuyama, K. Nagai : Appl. Phys. Lett., 63, 2627 (1993)

27) Y. Mori, H. Endo, Y. Hayashi : 応用物理, 61, 1044 (1992)

28) J. Kido, M. Kohda, K. Okuyama, K. Nagai : Appl. Phys. Lett., 61, $761^{\prime}$ (1992)

29) J. Kido, M. Kohda, K. Hongawa, K. Okuyama, K. Nagai: Mol. Cryst. Liq. Cryst., 227, 277 (1993)

30) J. Kido, K. Hongawa, K. Okuyama, K. Nagai : submitted for publication in Makromol. Chem., Macromol. Symp.

31) J. Kido, K. Hongawa, K. Okuyama, K. Nagai : Appl. Phys. Lett., in press. 